\title{
Study of Self-Fertilization of Alfala Medicago L. in Northern Trans-Urals
}

\author{
Dyukova N.N. \\ Doctor of Agricultural Sciences, professor \\ Federal State Budgetary Educational \\ Institution of Higher Education \\ «Northern Trans-Ural State Agricultural University» \\ Tyumen, Russia \\ natalya.dyukowa@yandex.ru
}

\author{
Kharalgyn A.S. \\ Candidate of Agricultural Sciences, associate professor \\ Federal State Budgetary Educational \\ Institution of Higher Education \\ «Northern Trans-Ural State Agricultural University» \\ Tyumen, Russia \\ acadagro@mail.ru
}

\begin{abstract}
In our research, $27-29 \%$ of alfalfa plants formed beans during self-pollination in the $I_{1}-I_{2}$ generations. At the same time, there was an increase in the number of plants that bound the beans under insulators in a closed flower without auto-tripping. This means that it is possible to obtain alfalfa seeds without the intervention of pollinators. The studies revealed a number of important points in the biology of alfalfa. First, no plants, in which all the flowers would open themselves, were found. Secondly, in subsequent generations, the number of plants that would not completely open flowers $(24.3 \%$ in the first, to $18.6 \%$ in the third generation of inbreeding), sharply decreased. It was found that both self-fertile and self-sterile plants exhibit auto-tripping. Breeding alfalfa in the Northern Urals should be aimed at creating self-fertile lines that would have high seed fertility, and at the same time, flowers that preserve the allogamic type of pollination. At first, the flowers do not open and only a week later, as a result of self-disclosing or self-fertilization, beans form in an undisclosed state. In this case, the possibilities of allogamy are used with the help of insects (if available), and in their absence, seed productivity is maintained due to high fertility during self-pollination. The alternation of allogamy with partial inbreeding will allow vegetative and seed productivity, resistance to diseases and pests, the intensity of growth and other economically valuable traits to be combined in new varieties of alfalfa.
\end{abstract}

Keywords - free pollination, tripping, auto-tripping, selfcompatibility, self-incompatibility

\section{INTRODUCTION}

In such a rapidly developing region of Russia as the Tyumen Oblast, conditions have been created for expanding and enlarging the livestock industry. The total need for animal feed is planned to be addressed through field feed production by 75 $80 \%$. Cultivation of perennial herbs in this regard is economically and energetically beneficial. The coefficient of energy efficiency of perennial grasses is 2.0-2.5 times higher than that of grain-feed crops. It is necessary to select such forage crops, the biological characteristics of which correspond to the soil and climatic conditions of the region [1].

In solving the problem of increasing the content of feed protein in animals' diets, alfalfa plays an important role. Alfalfa surpasses many feed crops, including legumes, by the quality of protein and the content of essential amino acids. One fodder unit of alfalfa contains on average 160 - 175 grams of digestible protein. Alfalfa protein is well digested and intensively absorbed by animals' organisms. Alfalfa is rich in vitamins and trace elements. Animals that eat green mass, hay, haylage, grass meal, pellets and briquettes made from alfalfa, are more enduring, they show improved reproduction capacity and accelerated growth [2].

In our opinion, the improvement of the feed base, first of all, by increasing the productivity and expanding the crops of alfalfa, is currently the most urgent problem. Alfalfa remains one of the most productive perennial leguminous plants.

Alfalfa crops in the region are limited. The main reasons are: lack of adapted varieties, seed production is poorly established, the technology of cultivation of alfalfa for green mass and seeds needs to be improved.

To eliminate the above reasons, studies are conducted on the question of pollination and fertilization of alfalfa plants. Special attention was given to the question in the second half of the last century, when the ecological situation deteriorated significantly. There was a lack of wild pollinating alfalfa insects and, as a result, low seed productivity was observed. There are two ways to solve this complex problem: to increase the number of insect pollinators or to increase the reproductive capacity of plants [3].

It is known that with the usual method of cultivation of a bloomed alfalfa flower, the column (the stamen tube together with the pestle enclosed in it) is tightly held in the flower boat with a special locking device and, as a rule, cannot be pulled out outside the flower and fertilization is excluded. When the flowers are opened by single bees or bumblebees, the column is released from the boat, and the stigma is in contact with pollen on the insect's body. At the same time, the protective mucus covering it is erased from the stigma and pollen transferred from other flowers sticks to it from insect's body. After contact with the body of an insect, the column hits with force the flower's sail and the stigma with its surface is pressed against it. Pollination of a flower occurs at the moment of its opening and contact with pollen on an insect's the body. Thus, the opening (tripping) of alfalfa flowers by insects plays an important role in pollination [4]. 
Later studies have revealed that the role of insects in the seed productivity of alfalfa has been exaggerated. It was found that plants of this culture, even in the presence of pollinators and in optimal ecological conditions, often give low yields of seeds, therefore the reason for low seed productivity must be sought in the biological nature of plants [5].

\section{GOAL AND RESEARCH TECHNIQUE}

The goal of our research is to study self-fertility and the ability to self-pollinate alfalfa plants in the Northern TransUrals for using the best forms in the breeding program.

Research (field) conducted in 2013 - 2017 in GAU of Northern Trans-Urals, in the zone of northern forest-steppe. By climatic conditions - this is one of the favorable areas for the cultivation of legumes. The meteorological conditions in the years of research were varied and reflected the climatic features of the region.

The alfalfa's self-fertility was determined by the number of beans that were formed with seeds from artificial selfpollination. The ability of the samples to self-pollination was determined according to the methodological guidelines [6]. Inbred lines were obtained on the basis of the varieties Omskaya 7 and Fast. The selection of material for the cultivation of each subsequent generation was carried out according to self-fertilization performance, which was determined by the number of cultivated beans with seeds from artificial self-pollination.

\section{CHARACTERISTICS OF PLANT MATERIAL}

The study included two varieties of alfalfa volatile (Medicago varia) - Omskaya 7 and Bystraya. The variety Omskaya 7 was bred in the Siberian Research Institute of Agriculture and the variety Bystraya at the State Agrarian University of Northern Trans-Urals. Under local conditions, Omskaya 7 variety forms, for two mowings, the yield of green mass $12.9 \mathrm{t} / \mathrm{ha}$, and the Bystraya variety - 19.6-25.0 t/ ha. This indicates the reserves of breeding work.

\section{RESULTS AND DiSCUSSION}

Seed productivity potential of an individual alfalfa plant is determined by genetic information embedded in the cell's constituent parts - the nucleus, chloroplasts and mitochondria (the plant genome), and at the level of a specific seeding - by the totality of all genes of this sort-population (the gene pool of the population). Alfalfa has great potential fruit formation, but they remain unfulfilled. Many researchers have found that in natural conditions only $13-35 \%$ of all flowers are pollinated, and out of 8-10 seedlets available, only in $2-5$ form seeds. The potential seed productivity of the best, zoned alfalfa varieties on average agrotechnical backgrounds can reach 3-4 tons / ha and higher, if conditions are provided for the development of each flower in a normal fruit and each ovule in a full-fledged seed [7].

According to R.R. Hill, J.L. Baylor [8], factors that affect the level of seed productivity of alfalfa: temperature and relative humidity of the air, the total amount of precipitation and their distribution during the growing season, the duration of solar illumination, the reserves of productive moisture under the grass during the entire period of flowering and fruit formation. It should be noted that all these factors act not separately, but in combination. They influence the intensity of pollination and the completeness of the setting of the beans as well as the number of seeds in the bean.

At the beginning of the last century, the cause of the emergence of auto-tripping, that is, the self-disclosure of alfalfa flowers, was investigated/formulated. It was found that at temperatures above $300{ }^{\circ} \mathrm{C}$, intensive hydrolysis of disaccharides begins in the cells, which leads to the increase in the osmotic pressure of the cell sap. As a consequence, the elasticity of the column becomes above the limit at which it can be held in the flower boat. The ability of plants to auto-trip was studied by R.P. Knowles [9], K. Lesins [10]. In the experiments of V.V. Koperzhinsky [11], it was found that when alfalfa is heated to $30-35 \mathrm{C}$ auto-tripping is observed in individual flowers, and at $50 \mathrm{C}$ this process already covers $75-80 \%$ of the flowers.

The study of the biology of pollination-fertilization and seed formation showed a great variation in the forms of alfalfa according to the intensity of flower disclosing - tripping. The inheritance of this property is intermediate in nature, and the signs of "light tripping" and "flowering intensity" positively correlate with fecundity. The high degree of heritability of light tripping can serve as a selection criterion in breeding for seed productivity [12].

Studies conducted by T.H. Busbice, O.J. Hunt, J.H. ElginJr, R.N. Peaden [13] showed that self-pollination seeds and beans formation in various forms of alfalfa varies in a wide range from 1.5 to $94.0 \%$ (of the number of self-pollinated flowers), and the number of seeds per 100 flowers ranges from 4 to 311 , and for one bean from 0.44 to 3.53. In the course of cytoembryological studies on plants from populations performed by the authors mentioned above, it was established that in the closed flowers of alfalfa pollen sprouts freely on the stigmas with an intact membrane and the pollen tubes penetrate into the ovary cavities. However, alfalfa has a selfincompatibility system, which makes fertilization of ovules difficult.

Our research in the Northern Trans-Urals focused on studying the effect of artificial tripping of alfalfa flowers on the developing of beans and seeds. During the flowering period, self-pollination was carried out by artificial dissection of 200 250 flowers on each studied variety. Labels tied to the number of tripping flowers were tied to all accounting racemes. To protect the flowers from pollination by insect pollinators, all accounting racemes are placed under gauze insulators. The level of self-fertility was determined by two indicators: the percentage of tripping flowers that form beans, and the number of seeds per tripping flower. The studied populations differed in their ability to tie beans when tripping flowers. The level of self-fertility in this case was $21.5-47.6 \%$. The plants in the populations had $0.89-1.14$ seeds per tripping flower. Thus, the average population self-fertility of alfalfa was within $30-45 \%$. We established an interrelation between the fertility of pollen and the self-fertility of the studied populations, the formation of beans and seeds during free pollination. Pollen fertility was 
determined by the average sample. At five random flowers that had just blossomed out, pollen was collected and two temporary preparations were made. Pollen was colored with acetocarmine. The amount of pollen was counted in ten fields of the microscope. On average, over the years of research, the studied alfalfa populations had a sufficient amount of fertile pollen ( 76 - 86\%) for self-pollination and for free pollination. [14].

According to M. Aycock, C. Wilsie [15], the process of selfcompatibility of alfalfa is hampered by the whole system of partial self-incompatibility, which prevents the growth of pollen tubes on the tissues of the self-pollinated pistil. In selfincompatible plants, three levels of inhibition of the fertilization process were found: inhibition of germinating pollen on the stigma of the pistil, inhibition of the growth of pollen tubes in the tissues of the column and incompatibility at the level of the ovule. Alfalfa's ability to set seeds under conditions of inbreeding varies from complete self-incompatibility to high self-compatibility. In plants with high self-fertility, there is no depression in the intake, and the average number of seeds in a bean in $I_{1}-I_{2}$ varies between $3.06-3.44$ pieces [16].

Thus, the theoretical basis of alfalfa breeding aimed at the increase in seed productivity as a result of the selection of plants with high self-compatibility was formulated. P. Melton [17] noted that this way it is possible to solve another important problem in the selection of herbs - to combine high vegetative and seed productivity in one genotype.

G.L. Stebbins [18] reported that self-pollination in higher plants is a mutation of the genetic systems responsible for crosspollination. The genes that control the property of selfincompatibility are the most ancient in the plant world.

Among the representatives of the genus Medicago L. there are different types: self-pollinating (about 40 species) and cross-pollinating. There is information about the transfer of plants from one breeding system to another. Moreover, the process of transition from self-incompatibility to autogamy in different plant species is reversible. Environmental factors such as temperature and air humidity can lead to changes in this process. Sunny, dry and warm weather during the flowering period, especially during the hottest hours of the day (from 11 am to $15 \mathrm{pm}$ ), is considered favorable for flower opening, germination of pollen, fertilization and summer of insect pollinators [19].

The study of self-pollination of alfalfa was conducted in the studies of V.K. Shumny and collaborators. Scientists have proposed to divide alfalfa populations into several groups according to the degree of self-pollination. The main group consisted of completely self-fertile plants, and the next one - of self-sterile forms. In their studies, the number of self-fertile plants from the number of self-pollinated was $14-18 \%$, depending on the variety. Most of the plants were partially fertile, with levels of seed formation ranging from 5 to $30 \%$ of flowers. Fully self-fertile plants in studies marked $1.3-5.0 \%$. Moreover, with an increase in self-fertility with inbreeding, fertility increased with free pollination. The correlation coefficient (r) between them was $0.16-0.37$; therefore, the selection of such forms will be difficult [20], [21].

Alfalfa incompatibility is controlled by polymeric genes and can manifest itself from the moment pollen germinates to the moment of seed formation. As a result of years of research, it was found that the setting of beans during self-pollination averaged $60.2 \%$. Self-fertile and self-sterile plants were present in each generation $\left(I_{1}-I_{5}\right)$. At the same time, self-fertile alfalfa plants accounted for $10.2-13.2 \%$, and self-sterile plants for 20.2 - 23.3\%. $76.2 \%$ of plants could form beans without mechanical tripping. The range of variation was from 0.1 to $50.0 \%$ on individual plants. The average beans formation level was $6.2 \%$ of the number of isolated flowers [22].

The obtained data are confirmed by the results of our research.

There are two types of beans formation under insulators in alfalfa plants in the absence of mechanical tripping: a) fertilization after self-disclosing of flowers (during autotripping); b) fertilization in a closed flower (without autotripping).

In our research, in alfalfa, $27-29 \%$ of the plants were tied up by beans during self-pollination in each of the $I_{1}-I_{3}$ generations. In generations, an increase in the number of plants that bound the beans under insulators in a closed flower without auto-ripping has been noted. Hence, there is the possibility of obtaining alfalfa seeds without the intervention of pollinators (Table 1).

TABLE I. STUDY OF MORPHOLOGICAL VARIABILITY IN ALFALFA INBRED LINES WHEN SELECTING FOR SELF-FERTILITY

\begin{tabular}{|c|c|c|c|c|c|}
\hline $\begin{array}{c}\text { Inbreeding } \\
\text { generation }\end{array}$ & $\begin{array}{c}\text { Number of } \\
\text { lines, } \boldsymbol{n}\end{array}$ & $\begin{array}{c}\text { Average self-fertility of } \\
\text { beans and seeds, } \%\end{array}$ & $\begin{array}{c}\text { Self-sterile } \\
\text { plants, \% }\end{array}$ & $\begin{array}{c}\text { Morphologically } \\
\text { modified plants, \% }\end{array}$ & $\begin{array}{c}\text { Character of } \\
\text { plant variability }\end{array}$ \\
\hline $\mathrm{I}_{0}$ & - & 28.6 & 24.5 & 1.1 & $\begin{array}{c}\text { Shape and size of } \\
\text { leaves }\end{array}$ \\
\hline $\mathrm{I}_{1}$ & 16 & 27.2 & 24.3 & 3.6 & $\begin{array}{c}\text { Flower size, stem } \\
\text { structure }\end{array}$ \\
\hline $\mathrm{I}_{2}$ & 23 & 28.5 & 19.8 & 3.4 & $\begin{array}{c}\text { Shape and size of } \\
\text { leaves, stem structure }\end{array}$ \\
\hline $\mathrm{I}_{3}$ & 17 & 29.4 & 18.6 & & 3.6 \\
\hline
\end{tabular}


A number of important points in the biology of alfalfa was identified. First, no plants were found in which all the flowers would open themselves. Secondly, in subsequent generations, the number of plants that would not completely open flowers $(24.3 \%$ in the first, to $18.6 \%$ in the third generation of the inlets), sharply decreased.

It was found that both self-fertile and self-sterile plants exhibit auto-tripping.

The selection of forms with auto-tripping in the in-dry process is possible only on the basis of self-fertile genotypes, since the bees do not attend the already discovered flower of alfalfa.

Many scientists are convinced that if self-revealing forms are produced on the basis of autogamy, then we can expect the combination of signs of cross-pollination and self-pollination in the same population. When auto-tripping plants are distinguished from self-incompatible forms, there is a real prospect of combining insect-pollination and wind-pollination of alfalfa. Alfalfa's wind pollination is associated with great difficulties due to the weak volatility of pollen, its size and stickiness.

As a result of our work, the form of alfalfa was obtained, in which the growth of pollen tubes and self-fertilization was carried out inside a closed flower. Therefore, it became possible to transfer cultivated alfalfa to typical self-pollination, which will become reliable only under a combination of all conditions: the incompatibility system, the method of pollination, and the structural characteristics of the flower. Probably, inbreeding treatment reduced the genetic diversity of populations and led to homozygosis with a weakening of the self-incompatibility genes' effect. In subsequent generations, no stability was observed in the manifestation of autogamy. Inbreeding caused the appearance of plants with impaired shape and size of the leaves, structure of the stem, size of the flower. Research in this direction is ongoing, so other facts may appear.

Some researchers believe that it is possible to reduce the decrease in vegetative power and seminal fertility or even eliminate depression by slowing down the forms of inbreeding - using self-pollination of one or two generations followed by crossing, including inbred and non-inbred related plants with simultaneous strict selection. It is assumed that under the influence of long-term selection for alfalfa seed productivity an evolutionary change occurs in the mode of reproduction - a partial replacement of outbreeding with inbreeding, associated with a weakening of the genetic mechanism for controlling outbreeding [23].

N.L. Kolyasnikova [24] wrote that with artificial tripping of alfalfa, the number of unfertilized ovules increases 2.6 times. This also increases the number of ovaries with degenerating fertilized ovules 2.2 times. The reasons can be both disturbances in the development of the endosperm, and disturbances in the development of the embryo. Disorders in the development of the endosperm manifest themselves at the stage of a club-shaped embryo. However, degeneration can begin with the embryo, while the endosperm nuclei have a normal appearance. In degenerating germ cells, the cytoplasm shrinks and lags behind the cell walls. Thus, after a single forced self- pollination, part of the ovules remains unfertilized, and some of the fertilized ovules degenerates. Ultimately, according to their data, only about $2 \%$ of ovules can produce seeds.

E.V. Kvasova, V.K. Noisy [25] reported that inbreeding differentiates populations by isolating auto-tripping and selfpollinating plants. Completely sterile or highly fertile forms can be selected starting from I_4- 『 I forming beans with seeds in isolation, without the access of pollinating insects will be especially valuable. Under natural conditions, such forms will retain their properties of autotripping and self-pollination. So it will be possible to form the source material for breeding plants with increased seed productivity. K. Lesins [26] published a report on the creation of a self-pollinated alfalfa line (Ellerslie 1).

Many specialists, including Americans, pay attention to the protection of seed plots from pests, the presence of pollinators and timely irrigation. Lastly, they pay attention to the variety as an element of seed productivity. In our opinion, a variety with weak reproductive ability does not pay back the costs aimed at obtaining a high yield of seeds [27].

\section{CONCLUSION}

Breeding of alfalfa in the Northern Urals should be aimed at creating self-fertile lines that would have high seed fertility, and at the same time, flowers that preserve the allogamic type of pollination. At first, the flowers do not open and only a week later, as a result of self-disclosing or self-fertilization, beans form in an undisclosed state. In this case, the possibilities of allogamy are used with the help of insects (if available), and in their absence, seed productivity is maintained due to high fertility during self-pollination. The alternation of allogamy with partial inbreeding will allow vegetative and seed productivity, resistance to diseases and pests, the intensity of growth and other economically valuable traits to be combined in new varieties of alfalfa..

\section{References}

[1] G.S. Posypanov, Plant cultivation. Mocow: Koloss, 2006, p. 611

[2] G.I. Makarova, Perennial forage grasses of Siberia. Omsk: West Siberian Prince. publishing house, 1974, p. 248

[3] Yu.A. Pesenko, Lucerne bee leaf cutter and its development for pollinating alfalfa. Leningrad: Nauka, 1982, p. 136

[4] E.N. Sinskaya, Lucerne - Medicago sativa L., Cultural flora of the USSR. Moscow: Selkhoziz, 1950, vol. 13, p. 570

[5] L.I. Orel, V.F. Ogorodnikov, E.V. Semenova, "Effect of embryological characteristics of alfalfa, clover and beans on their seed productivity", Genetic methods for the selection of forage grasses, Vilnius, 1987, pp. 34 -35 .

[6] A.I. Ivanov, N.I. Dzyubenko, A.V. Bukhteeva, Guidelines for the conduct of self-pollination and hybridization, taking into account self-fertility and auto-ripping in alfalfa, Leningrad: VIR, 1982, p. 15.

[7] N.M. Savelyev Biological basis of cultivation of seed alfalfa in Western Siberia. Moscow: Publishing House of the Academy of Sciences of the USSR, 1960, p. 350.

[8] R.R. Hill, J.L. Baylor, "Genotype $\mathrm{x}$ environment interaction analysis for yield in alfalfa", Crop Seience, 1983, no. 5, pp. 811-815. 
[9] R.P. Knowles, "The role of insects, weather conditions and plant character in seed setting of alfalfa", Sci. Agr., 1943, No. 24, pp. $29-50$.

[10] K. Lesins, "Investigation into seed setting of Lucerne at Ultuna", Sweden 1945 - 1949, Ann. Rov. Agr. Coll. Sweden, 1950, No. 17, p. 441.

[11] V.V. Koperzhinsky, Biology of flowering and the formation of seeds and nutrition of the generative organs of alfalfa, Extended abstract. of dis. xand. agr. Sciences. Balashikha, 1948, p. 14

[12] E. Tellhelm, "Untersuchugen uber die Ertragsleistung und Qualitatseigenschaften von Luzernesorten", Theoret. Appl. Genet., 1980, vol. 38 , No. 5 , pp. $204-212$.

[13] T.H. Busbice, O.J. Hunt, J.H. Elgin Jr, R.N. Peaden, "Evaluation of the effectiveness of polycross and self-progeny test in increasing the yield of alfalfa synthetic varieties”, Crop. Sci., 1974, vol. 14, No. 1, pp. 8-11.

[14] N.N. Dyukova, A.S. Kharalgin, "Aspects of seed productivity of alfalfa in the Northern Trans-Urals", Agrarian Bulletin of the Urals, 2017, No. 2., pp. 33-36.

[15] M.K. Aycock, C.P. Wilsie, Inbreeding M. sativa L. by submitting. 2. Agronomic trains, Crop. Sci., 1968, vol. 8, No. 4, pp. $481-485$.

[16] J. Sinska, "Vplyv insuchtu a selekcie na fertility Lucerny", Vedescke prace vyckumnehe ustavu rastlinnes vyroby v piestanoch, Krmoviny, 1979, No 16, pp. $40-51$.

[17] B. Melton, "Comparative seed and forage yield in crosses of selected alfalfa clones as compared to polycross progeny", Crop. Sci., 1969, No. 7 , pp. $253-255$.

[18] G.L. Stebbins, "Self-fertilisation and population variability in their-higher plants", Amer. Naturalist, 1957, No. 41, p. 337.
[19] V.I. Kovalenko, S.S. Ibragimova, V.K. Noisy, PS Lapteva, A.V. Laptev, "Tripping and the evolution of the breeding systems of species of the genus Medicago L.”, Selskokhoz. biology, 1987, No. 8, pp. 35 - 40.

[20] E.V. Kvasova, V.K. Noisy, "Polymorphism of Alfalfa Population on the Basis of Breeding Systems", Izvestia Sibir. Dep. Academy of Sciences of the USSR. Biol Series Sciences, 1983, No. 15/3, pp. 94 - 100.

[21] E.V. Kvasova, V.K. Shumny, "Inbreeding in Alfalfa", Bulletin of Siberia. Dep. Academy of Sciences of the USSR. Biol Series Sciences, 1981, No. 15 , pp. $28-34$.

[22] E.V. Kvasova, V.K. Shumny, "Cytoembryological studies of the mechanism of incompatibility in alfalfa", Questions of theoretical and practical genetics, Novosibirsk, 1974, pp. 37 - 47.

[23] A.F. Bober, O.K. Mirata, I.V. Bashkirova, A.A. Kuorchinsky, "Selfcompatibility and seed productivity of alfalfa", Kiev, 1981, pp. 5-7. [Proc report 4th Congress of Geneticists and Breeders of Ukraine, Part 4, 1981]

[24] N.L. Kolyasnikova, Reproductive biology of cultivated and wild leguminous grasses due to the low seed productivity, extended abstr. of disser. for doctor biologist. Sciences, Perm, 2005, p. 49.

[25] E.V. Kvasova, V.K. Noisy, "Prospects for the use of autogamy in the breeding of alfalfa for increased seed productivity", Genet. methods in the selection of feed grasses, Vilnius, 1987, pp. 15 - 16.

[26] K. Lesins, "Self-pollinating alfalfa Allerslie 1", Agrologist, 1977, vol. 6, No. 2, p. 26.

[27] N.N. Dyukova, A.S. Kharalgin, A.A. Bogomolov, "Formation of Alfalfa Seed Yield in the Northern Trans-Urals", Agrarian Bulletin of the Urals, 2013, No. 9, pp. 14 - 16. 